\title{
THE TRANSLATOR'S SLEIGHT OF HAND: ROBERT L. SCOTT-BUCCLEUCH AS UNRELIABLE READER OF DOM CASMURRO
}

\author{
JAMES R. KRAUSE \\ Brigham Young University \\ Provo, UT, EUA
}

\begin{abstract}
Robert L. Scott-Buccleuch's translation of Dom Casmurro has gained notoriety for excluding nine of the original's 148 chapters. Once this editorial imposition came to light, critics have reacted strongly against him for abridging one of the most celebrated novels of Brazil's most revered writer. The excision of nine chapters, however, cannot be disregarded as a mere error of interpretation; it was a deliberate and calculated decision on the part of a highly engaged reader. In fact, one could argue that Scott-Buccleuch's deletion imitates many of the narrative techniques of the novel's narrator-protagonist. Studying this controversial translation enhances our understanding of the underlying metanarrative structure of Dom Casmurro, especially in regards to the relationships between author, narrator, and reader.
\end{abstract}

Keywords: Dom Casmurro, Translation, Scott-Buccleuch.

\section{A PRESTIDIGITAÇÃO DO TRADUTOR: ROBERT L. SCOTT-BUCCLEUCH COMO LEITOR NÃO CONFIÁVEL DE DOM CASMURRO}

Resumo: A tradução inglesa de Dom Casmurro de Robert L. Scott-Buccleuch é notória por excluir nove dos 148 capítulos originais. Quando chegou à luz essa imposição editorial, os estudiosos reagiram vigorosamente contra ele, por condensar um dos livros mais celebrados de um dos escritores brasileiros mais consagrados. A exclusão de nove capítulos, porém, não deve ser considerada um mero erro de interpretação; foi uma decisão deliberada e calculada por parte de um leitor altamente engajado com o texto. De fato, pode-se discutir que a supressão feita por Scott-Buccleuch imita muitas das técnicas narrativas empregadas pelo narrador-protagonista. Uma análise cuidadosa dessa tradução polêmica até reforça nossa compreensão da estrutura da subjacente metanarrativa de Dom Casmurro, sobretudo a respeito das relações entre autor, narrador e leitor.

Palavras-chave: Dom Casmurro, Tradução, Scott-Buccleuch. 
$[W]$ ith enough time, enough afterlife, a great book does find its rightful place. And perhaps some books deserve to be rediscovered again and again.

Susan Sontag, Afterlives: The Case of Machado de Assis, p. 39.

s years pass, more and more critics - both within and without the
field of Latin American literature - acknowledge and celebrate the
genius of Joaquim Maria Machado de Assis (1839-1908). By the late 1960s, notable US writers, such as John Updike and John Barth, had read Machado in English translation. ${ }^{1}$ Nevertheless, critics outside of Brazilian studies in the United States have "discovered" the author only recently. In a 1990 article in The New Yorker, Susan Sontag calls Machado "the greatest author ever produced in Latin America". ${ }^{2}$ In 2002 Harold Bloom included Machado in Genius as one of the one hundred exemplary creative minds in world literature, naming him "the supreme black literary artist to date". ${ }^{3}$ Roberto González Echevarría views Machado as "the premier nineteenthcentury Latin American writer and one of the best of all time", ${ }^{4}$ insisting "he must be regarded as one of Latin America's first world-class writers". ${ }^{5}$ As a precursor to many of the narrative developments of Latin American and world literature in the twentieth century, Machado de Assis continues to receive accolades. Earl Fitz, a proponent of studying Machado's work within

\footnotetext{
${ }^{1}$ See UPDIKE, Conversations with John Updike; and FITZ, John Barth, Machado de Assis and 'The Literature of Exhaustion'.

${ }^{2}$ SONTAG, cit., p. 107. In that same year, Sontag provided the introduction to a reprint of William Grossman's 1951 English translation of Memórias póstumas de Brás Cubas, published as Epitaph of a Small Winner.

3 BLOOM, Genius, p. 674. In 2002, in The New York Review of Books, Michael Wood considered Machado "one of the world's great writers". WOOD, Master among the Ruins. In 2008 in The New York Times, Larry Rohter noted that "Allen Ginsberg described him as 'another Kafka"', that Philip Roth recently "drew parallels between Machado and [Samuel] Becket", and that Donald Barthelme "claimed him as an influence". ROHTER, After a Century, a Literary Reputation Finally Blooms. For more information regarding Machado's reception in English see: FITZ, John Barth, Machado de Assis and 'The Literature of Exhaustion'; FITZ, The Reception of Machado de Assis in the United States during the 1950s and 1960s; and MOREIRA, O lugar de Machado de Assis na república mundial das letras.

${ }^{4}$ GONZÁLEZ ECHEVARRÍA, Introduction, p. 95.

${ }^{5}$ Idem, p. 16.
} 
a comparative context, affirms: "Machado de Assis deserves recognition not merely as Brazil's first great novelist but as one of the true masters of modern narrative in the Western tradition". ${ }^{6}$ Machado's reception in English has been overwhelmingly positive, despite any perceived shortcomings in previous translations of his work. Bloom, for example, claims Machado had been represented "only by inadequate translations" ${ }^{7}$ until the recent translations by Gregory Rabassa and John Gledson. ${ }^{8}$ Bloom's somewhat dismissive assessment does not hold up to close scrutiny, except perhaps in the case of Robert L. Scott-Buccleuch's ${ }^{9} 1992$ translation of Dom Casmurro. ${ }^{10}$

In a 1997 column in Globo, Brazilian writer Affonso Romano de Sant'Anna reported what he deemed to be a significant flaw in ScottBuccleuch's translation. ${ }^{11}$ According to Sant'Anna, his friend Zulfikar Ghose, a Pakistani-American writer, discovered the error while teaching at the University of Texas at Austin. One day, he asked his students to turn to a passage, referring to his copy of Helen Caldwell's serviceable but out-ofprint translation. ${ }^{2}$ His befuddled students, using the more recent Penguin edition, replied it was nowhere to be found, for "its translator [had] cut out

\footnotetext{
${ }^{6}$ FITZ, Machado de Assis, p. 22.

${ }^{7}$ BLOOM, cit., p. 675.

8 The Posthumous Memoirs of Brás Cubas (1881) [trans. Rabassa, 1997]; Quincas Borba (1891) [trans. Gregory Rabassa, 1998]; Dom Casmurro (1899) [trans. John Gledson, 1997].

9 Robert Lascelles Scott-Buccleuch, originally from Scotland, moved to Brazil to work as the superintendente da Cultura Inglesa do Rio de Janeiro (ALMEIDA, Três traduções de Dom Casmurro, p. 38). He helped establish the English Language and Literature Department at the Universidade Federal de Brasília (BARBOSA, The Virtual Image, p. 123). In 1976 the Brazilian government awarded him the Ordem de Rio Branco for services rendered and shortly thereafter the Academia Brasileira de Letras awarded him the Medalha Machado de Assis (BARBOSA, cit., 123; ALMEIDA, cit., p. 8, 38). During the 1970s he translated four works of Brazilian fiction: Machado de Assis's Iaiá Garcia [Yayá Garcia, 1976]; José Américo de Almeida's A bagaceira (1928) [Trash, 1978]; Lima Barreto's O triste fim de Policarpo Quaresma (1915) [The Patriot, 1978]; and Graciliano Ramos's São Bernardo (1934) [1979]. In 1990 he translated Machado's Memorial de Aires (1908) as The Wager: Aires' Journal. His translation of Dom Casmurro, originally published by Peter Owen Ltd. as Lord Taciturn, was acquired by Penguin in 1994 and included in their "Classics" series (GLEDSON, Translating Machado de Assis, p. 8; KREMER, Desvendando, p. 4005).

10 The first English translation of Dom Casmurro was published in "London in 1953 by Helen Caldwell, the great Machadian scholar and translator, but did not appear in America until 1966" (JACKSON, Madness in a Tropical Manner). See also JACKSON, Machado de Assis in English, p. 627-646, for an annotated bibliography of works in English translation as well as an extensive list of critical works written in English about Machado.

${ }^{11}$ Three years earlier, Heloisa Gonçalves Barbosa noted the nine omitted chapters in her dissertation, The Virtual Image: Brazilian Literature in English Translation, p. 158.

12 Noonday Press first published Helen Caldwell's translation of Dom Casmurro in 1953 but did not appear in the United States until the University of California Press reprinted it in 1966 (JACKSON, Madness in a Tropical Manner).
} 
several chapters from it and with a carpenter's tongue-and-groove sleight of hand so bridged the gap that the novel appeared unabridged". ${ }^{13}$ The professor and his students discovered that the British version excluded nine of the 148 chapters with no indication that the translation was an abridgement. Ghose wrote a strongly worded letter to Penguin, in which he informed them of "their translator's deception"14 and requested they recall the book. Penguin offered no reply. This particular translation of Dom Casmurro has gained a level of notoriety among academics, especially those who study the reception of Machado de Assis in English. In the aforementioned column, Sant'Anna denounced Scott-Buccleuch's "crime" against the memory of Machado and called upon the Academia Brasileira de Letras (ABL) for an official response. The next day, also in Globo, Josué Montello, member of the ABL - although not acting in an official capacity condemned Scott-Buccleuch's disrespectful attitude toward Machado. Heightening the hyperbolic rhetoric, Montello encouraged Brazilian writers to express their collective indignation through "vias diplomáticas". ${ }^{15}$

While their frustration is understandable, the polemic reveals widespread attitudes concerning fidelity in translation, specifically in regards to Brazil's most celebrated and revered writer. Sant'Anna judges Scott-Buccleuch's attempt to improve the original as a "mutilação do texto machadiano"16 and lumps him together with a group of translators he compares to parasites, who end up "deformando e até matando o hospedeiro". ${ }^{17}$ Montello refers to Scott-Buccleuch's editorial impositions as "mudanças abusivas", ${ }^{18}$ turning Machado's works into "livros desvirtuados". ${ }^{19}$ While desvirtuar means to misinterpret or misrepresent, it also means to strip something of its moral virtue, implying the translator has performed an act of sexual violence against Machado's text. Even Anglo critics have adopted an accusatory tone. K. David Jackson inculpates Scott-Buccleuch of "[butchering] the novel". ${ }^{20}$ Alfred Mac Adam states: "the British version perpetrated by R. L. Scott-Buccleuch is an abomination". ${ }^{21}$ In "Machado in

\footnotetext{
${ }^{13}$ GHOSE, Reading Joaquim Maria Machado de Assis.

${ }^{14}$ Idem.

15 Tradução inglesa altera livro de Machado de Assis. O Globo, 6 Aug. 1997.

${ }^{16}$ SANT'ANNA, Atentado contra Machado.

${ }^{17}$ Idem.

18 Tradução inglesa altera livro de Machado de Assis. O Globo, 6 Aug. 1997.

${ }^{19}$ Idem.

20 JACKSON, Madness in a Tropical Manner.

${ }^{21}$ MAC ADAM, Dead Man Talking, p. 28. The only neutral critique of Scott-Buccleuch's translation appears to be Mark Dinneen's write-up for Encyclopedia of Literary Translation into English: "Scott-
} 
English", Daphne Patai takes a more even-handed approach in comparing the Caldwell and Scott-Buccleuch translations of Dom Casmurro, yet she ultimately adopts a disapproving stance toward the latter in order to exalt the former. The Scott-Buccleuch translation has since gone out of print "after the scandal of its omission of nine chapters became public knowledge". 22

In his translation of Dom Casmurro, Scott-Buccleuch attempts to perform a textual sleight of hand. The main reason why critics have disparaged this translation is because, unlike the skilled magician who never reveals his tricks, Scott-Buccleuch got caught. The excision of nine chapters, however, cannot be disregarded as a mere error of interpretation; it was a deliberate and calculated decision on the part of a highly engaged reader. Although the purpose of this article is not to vilify the translator for daring to abridge Machado's magnum opus, we must recognize that his decisions have interpretational consequences. Whether or not the translation is misrepresentative or flawed, studying the effects of the abridgment enhances our understanding of the metafictional underpinnings of Dom Casmurro, specifically the relationships between author, narrator, and reader.

In his explanatory note, Scott-Buccleuch offers no indication that his translation is an abridgment. He does, however, mention the difficulties in translating Machado's prose, describing it as "virtually impossible to render satisfactorily in English". ${ }^{23}$ In spite of his apparent awareness of Machado's "concise, terse, almost epigrammatic" ${ }^{24}$ style, Scott-Buccleuch deemed nine chapters to be superfluos in what Patai considers an "elliptical but essential middle section of the novel". 25 The translator removed the following chapters: 52 , most of 54, 55, the first paragraph of 56, 57-60, 63 and $64 .^{26}$ Although we can only speculate as to why he eliminated some passages and not others, Patai reasons that his "deletion of whole chapters suggests that his concern was directed [...] to what he considered an appropriate structure and rhythm in a novel". ${ }^{27}$ She continues:

Buccleuch is freer with regard to diction and sentence structure and his English reads more naturally, but he condenses the original text by omitting several chapters" (DINNEEN, Dom Casmurro, p. 881).

22 GLEDSON, cit., p. 18.

${ }^{23}$ SCOTT-BUCCLEUCH, Introduction, p. 9.

${ }^{24}$ Idem, p. 8.

${ }^{25}$ PATAI, Machado in English, p. 96.

${ }^{26}$ For a succinct overview of the chapters Scott-Buccleuch removes and combines see PATAI, Machado in English, p. 96-97.

${ }^{27}$ Idem, p. 99. 
For what his excisions succeed in accomplishing is to sacrifice the narrative to the plot, which, Scott-Buccleuch seems to think, must proceed with as few impediments as possible. The pieces of Machado's carefully fragmented narrative have, as a result, been neatly reassembled and locked into place by his translator. ${ }^{28}$

Nevertheless, if improved pacing of the plot has been gained, what has been lost? Patai observes:

He has largely suppressed the theme of [Dom Casmurro's] ${ }^{29}$ effort to construct a seamless web, an effort in which he is constantly frustrated by his own digressions. In other words, [Scott-Buccleuch] has eliminated much of the metanarrative that is absolutely crucial to understanding [Dom Casmurro] and his task in composing the story we ostensibly have before us [...]. ${ }^{30}$

In contrast to other critics, Patai offers a measured critique of ScottBuccleuch's apparent misreading of the underlying yet fundamental metanarrative structure of Dom Casmurro. Undoubtedly, the translator hampers his reader's ability to engage with the metanarrative by removing sections that he perceives to be superfluous. Notwithstanding, if a translation - as Gregory Rabassa argues - is the closest possible reading of a given text, ${ }^{31}$ then it stands to reason that Scott-Buccleuch's decision to remove these chapters was not arbitrary and haphazard but deliberate and decisive. While we may never know his motives in removing certain sections, we can examine the extent to which he interacts with the novel as a participatory reader. Moreover, we can assess the effects his translation decisions have on the metanarrative and metafictional aspects of the novel.

Before we analyze the excised chapters, however, we must briefly discuss the nature of the novel's metanarrative that is weakened by the abridgement. Marta Peixoto observes that "[t]he key to interpreting Dom

\footnotetext{
${ }^{28}$ Ibidem.

${ }^{29}$ Critics vary in how they refer to the narrator-protagonist of Dom Casmurro. While there are three names used for the three stages of his life - Bentinho, the boy and young man; Bento Santiago, the adult; and Dom Casmurro, the old man who is the irascible author of the text - I will refer to the narrator as Dom Casmurro throughout my study in order to maintain consistency and to avoid confusion.

30 PATAI, Machado in English, p. 97.

${ }^{31}$ RABBASSA, No Two Snowflakes are Alike, p. 6.
} 
Casmurro lies with the narrator-protagonist and with our view of his designs and possible covert purposes". ${ }^{32} \mathrm{He}$ discusses the process of writing "on almost every page, indulging in the famous seemingly casual digressions that mark the novel's style and that only a careful reading reveals to be pertinent (in most cases) to the main narrative". ${ }^{33}$ Silviano Santiago was one of the first Brazilian critics to examine the deeper narrative structure at play as well as Machado's aim in creating a new kind of narrator: "[Machado de Assis] deseja que [Dom Casmurro] se torne mais ambíguo, mais sutil, e para isso suprime o narrador onisciente e que explicava os fatos de uma plataforma divina, e dá toda a responsabilidade da narração ao personagem ciumento". ${ }^{34}$ Santiago calls this narrative technique "a retórica da verossimilhança", in which Dom Casmurro employs language and rhetorical devices to manipulate and persuade the reader to accept Capitu's guilt and his own innocence as the only plausible situation. Following suit, contemporary readings of Dom Casmurro tend to downplay questions of Capitu's infidelity, choosing to highlight, instead, Machado de Assis's innovative narrative and metafictional techniques that ultimately undermine the narrator's argument. Peixoto observes:

It seems impossible to disagree with the current prevailing critical opinion that the novel offers an exceedingly well-crafted example of a first-person narrator who, while placing the blame for grave misdeeds on other characters, ends up incriminating himself. Most current readers agree that the novel does not leave open the question of adultery for readers to decide as they see fit but rather blocks the possibility of a final decision of moral judgment. ${ }^{35}$

\footnotetext{
32 PEIXOTO, Dom Casmurro by Machado de Assis, p. 219.

${ }^{33}$ Idem, p. 219.

${ }^{34}$ SANTIAGO, Retórica da verossimilhança, p. 35.

35 PEIXOTO, cit., p. 220. Paul Dixon points out that reading the indeterminacy of the issue of adultery has been largely characteristic of North American critics, including Waldo Frank, Keith Ellis, Arthur Brackel, Earl Fitz, as well as himself. Celebrated Brazilian critics, such as José Veríssimo, Lúcia Miguel Pereira, Barreto Filho, Afrânio Coutinho and Érico Veríssimo tended to side with the perspective of Dom Casmurro, that is, condemning the supposed infidelity of Capitu. DIXON, Dom Casmurro e o leitor, p. 217-18. With the publication of Helen Caldwell's foundational study, The Brazilian Othello of Machado de Assis, in 1960 - and the subsequent critical reception and response by Silviano Santiago in 1969 ("A retórica da verossimilhança") and Roberto Schwarz in 1991 (Um mestre na periferia do capitalismo) - Capitu's image of innocence gained a stronger foothold in Brazilian literary criticism. Notwithstanding, Brazilian critics were inclined to favor those readings that examined the themes of race and gender, as well as the culture, history, and economics of nineteenthcentury Brazilian society in Rio de Janeiro over narratological, reception, and reader-response studies. Idem, p. 218. For further information on the differences and similarities between the critical reception
} 
In recent years, critics have focused less on what Dom Casmurro includes in his narration and more on how he constructs his story. João Adolfo Hansen observes: "the decisions about the narration are more fundamental than the events of the story itself, because they call readers' attention to the act of the invention of the text itself". ${ }^{36}$ Fitz agrees that Dom Casmurro's "telling of the story gradually emerges as the novel's clandestine theme". ${ }^{37}$ The story of perceived adultery, therefore, is not nearly as important as the way in which the narrator undermines his own argument by introducing digressions, contradictions, and subversions that underscore his unreliable nature. ${ }^{38}$ As we will now see, Scott-Buccleuch's decisions to exclude specific chapters destabilizes this underlying yet fundamental metanarrative structure, preventing readers from accessing the breadth and depth of Machado's narrative innovations.

Of the nine removed chapters, three stand out in regards to the importance of the underlying metanarrative structure: chapter 55, "Um soneto"; chapter 59, "Convivas de boa memória"; and chapter 60, "Querido opúsculo". Moreover, the metafictional underpinnings of these chapters further strengthen the interweaving relationships between author, narrator, and reader that Machado de Assis develops throughout the novel, ${ }^{39}$ aspects of which Scott-Buccleuch's reader is deprived.

of Machado in the United States and Brazil see: DIXON, Machado de Assis, the 'Defunto Autor' and the Death of the Author, p. 53-54, and BAPTISTA, O legado Caldwell, ou o paradigma do pé atrás, p. 161-162,

${ }^{36}$ HANSEN, The Fruit and the Rind: An Afterword, p. 248.

${ }^{37}$ FITZ, Machado de Assis, 53.

38 Although Wayne C. Booth first coined the term "unreliable narrator" in The Rhetoric of Fiction (1961), Peter J. Rabinowitz's definition of the term more closely aligns with Dom Casmurro's role as first-person narrator: "An unreliable narrator however, is not simply a narrator who 'does not tell the truth' [...]. Rather an unreliable narrator is one who tells lies, conceals information, misjudges with respect to the narrative audience - that is, one whose statements are untrue not by the standards of the real world or of the authorial audience but by the standards of his own narrative audience". RABINOWITZ, Truth in Fiction, p. 133-134.

${ }^{39}$ For the purposes of this article I have refrained from entering the murky narratological waters of identifying and categorizing the various kinds of readers present in Dom Casmurro. It behooves us, however, to note that Machado's efforts in creating a new narrator necessitate a new reader. The internal "leitor" and "leitora" of Dom Casmurro's text straddle the boundary between implied reader and narratee. Context indicates whether "reader" refers to the internal receptor of Dom Casmurro's narration, the external reader of Machado de Assis's novel, or the receiver of Scott-Buccleuch's translation. Likewise, I have largely avoided parsing the roles of author and the "notoriously indefinite or even indefinable implied author" (Nünning, p. 16). For a thorough discussion on the multiplicity of readers and their interactions with narrator and author in Dom Casmurro, see the following: CÂMARA, Machado de Assis e as referências ao leitor; DIXON, A autorreferência e o paradoxo em Dom Casmurro; VALLE, Os narradores de Machado de Assis; GUIMARÃES, Os leitores de Machado de Assis; and DIXON, Dom Casmurro e o leitor. 
In Chapter 55, "O soneto" - one of many examples of self-reflexivity and self-critique found throughout the novel - Dom Casmurro discusses a sonnet he started yet never finished while in the seminary. Only two verses make up the sonnet: the opening, "Oh! flor do céu! oh! flor cândida e pura!", and the closing, "Perde-se a vida, ganha-se a batalha!". 40 The juxtaposition of life ("flor") and death ("perde-se a vida") mirrors Dom Casmurro's own attempts to recover the memories of youth in his old age. After expressing frustration in never having finished the sonnet, he invites his readers to write the missing verses, to fill in the gap between the beginning and the end, that is, to add the interpretation that any good modern narrative requires: "dou esses dois versos ao primeiro desocupado que os quiser. Ao domingo, ou se estiver chovendo, ou na roça, em qualquer ocasião de lazer, pode tentar ver se o soneto sai. Tudo é dar-lhe uma ideia e encher o centro que falta". ${ }^{41}$ Just as the narrator-protagonist invites his reader to finish the sonnet and participate in artistic co-creation, Machado de Assis invites us as readers to fill in silences of Dom Casmurro's missing middle years.

Furthermore, this chapter metaphorically mirrors and reinforces the thematic structure of the novel introduced in the second chapter of the novel, "Do livro.” Doris J. Turner observes that Dom Casmurro's narration "subtly reveals that the ambiguous first and last lines of the unwritten sonnet imaginatively parallel and re-echo the first and last lines of his own life." 42 At the beginning of the novel, now living in Engenho Novo he explains his objective in constructing an exact replica of the home in which he was raised on rua Matacavalos:

O meu fim evidente era atar as duas pontas da vida, e restaurar na velhice a adolescência. Pois, senhor, não consegui recompor o que foi nem o que fui. Em tudo, se o rosto é igual, a fisionomia é diferente. Se só me faltassem os outros, vá; um homem consola-se mais ou menos das pessoas que perde; mas falto eu mesmo, e esta lacuna é tudo. ${ }^{43}$

His stated purpose, therefore, is to recover the happiest moments of his life - his childhood - in his old age. In this way he attempts to fill in the mysterious void of the middle years of his life. This profound incoherence between these two time periods, as Rex Nielson argues, shows that at some

\footnotetext{
40 All citations of Machado's originals in Portuguese are from ASSIS, Romances e contos em hipertexto, edited by Marta de Senna.

${ }^{41}$ Idem.

42 TURNER, A Clarification of some 'Strange' Chapters in Machado's Dom Casmurro, p. 59.

${ }^{43}$ ASSIS, cit.
} 
point there occurred "uma ruptura [de] sua identidade". ${ }^{4}$ This rupture points to a "lacuna", which is the source of his restiveness and anxiety as his life draws to a close. When he says "falto eu mesmo", he refers to "what should have been the best, most fruitful and loving years of his life". ${ }^{45} \mathrm{He}$ recognizes the futility of this endeavor since recreating the physical surroundings ("o rosto") fails to reproduce the internal feelings of happiness and joy ("a fisionomia"). When the architectural reconstruction fails to provide Dom Casmurro with the solace he seeks, he turns to the power of self-writing. Fitz suggests that his unstated purpose in writing is "to expiate the guilt that gnaws at him but that he cannot - or will not - openly acknowledge". ${ }^{6}$ On one hand, Dom Casmurro seeks catharsis through the act of writing as he hopes to relieve his guilt for driving away his wife, son, and best friend. On the other hand, as Helen Caldwell argues in The Brazilian Othello, Dom Casmurro seeks to justify his cruel and implacable actions by proving Capitu's guilt to his readers. Yet Dom Casmurro's act of writing is not merely an exercise of self-exploration, as the narrator would have his readers believe; rather, his narration is calculated and premeditated. Santiago observes that the narrator's text "obedece a desígnios apriorísticos, óbvios ou camuflados, mas sempre sob o devido controle daquele que lembra, que escreve [...]". ${ }^{47} \mathrm{He}$ continues: "[A] reconstituição do passado obedece a um plano predeterminado (cujo exemplo concreto dentro do tecido narrativo seria a reconstrução da casa de Matacavalos, que mostra em si toda artificialidade do processo) e sobretudo a um arranjo convincente e intelectual da sua vida". ${ }^{48}$ The narrative before us suppresses the years following Capitu's exile and by not including this portion of his life, Dom Casmurro textually preserves the "lacuna" of those missing years. Due to the numerous digressions, fissures, contradictions, and intentional gaps in his memory, readers begin to suspect Dom Casmurro of ulterior motives in writing his life's history. In his attempts to join together the two ends of his life, he effectively undermines his own argument, which only becomes apparent when the reader analyzes the self-reflexivity interwoven throughout the narrative. Turner observes: "symbolically, the novel is the sonnet, as both have the same vital skeletal configuration - an ambiguous

\footnotetext{
${ }^{44}$ NIELSON, A repetição e os retratos do pai e do filho em Dom Casmurro, p. 30.

${ }^{45}$ FITZ, Machado de Assis, p. 54.

${ }^{46}$ Idem, p. 53.

${ }^{47}$ SANTIAGO, cit., p. 38.

${ }^{48}$ Idem, p. 38.
} 
first and last line". ${ }^{49}$ Certainly "O soneto" is not the only section of the novel to reflect the themes found in the second chapter, ${ }^{50}$ but Scott-Buccleuch's removal of this episode deprives his readers of the opportunity to make the internally reinforcing connection between these two chapters.

Chapter 59, "Convivas de boa memória", is perhaps the axis around which the elliptical section revolves. With its deletion the reader misses a crucial aspect in understanding the complex relationship between author, narrator, and reader developed in Dom Casmurro. While commenting on the act of writing, the narrator questions the accuracy of his own memory, thus calling into question his reliability. Dom Casmurro comments on the desire to utilize writing to process the memories of his adolescence. He freely admits, however, that his memory is fallible. The fact that he cannot remember the name of the writer he paraphrases - "mas era um antigo, e basta"51 - demonstrates how easily he glides over specific details when a broader perspective suffices. If these details are inconsequential, then perhaps Dom Casmurro paints his memories in broad strokes, consciously leaving out specific details simply due to the fact that he cannot remember, or that he chooses not to remember. As in other parts of the novel, Dom Casmurro readily admits his memory is imperfect: "Não, não, a minha memória não é boa". ${ }^{52}$ Moreover, the comparison of his memory to "alguém que tivesse vivido por hospedarias" 53 who goes through life forgetting "caras" and "nomes", is striking because throughout his narration he has been able to recall, in great detail, the names and mannerisms of all the significant people of all the noteworthy events of his life. Either Dom Casmurro truly is forgetful, or he has a selective memory, choosing which elements to highlight and which to suppress. This second supposition is more likely in spite of his numerous claims that his memory is faulty. He draws attention to his unreliability even though his narration is highly detailed. Incongruities such as these cast shadows of doubt on his reliability and the reader wonders whether or not Dom Casmurro's claims of a poor memory are simply a ruse. In the second half of this chapter, the narrator directly connects his forgetfulness and confusion to the act of writing:

\footnotetext{
49 TURNER, cit., p. 61.

50 In chapter 64, "Uma ideia e um escrúpulo", also removed from Scott-Buccleuch's translation, Dom Casmurro again reminds his reader of his goal in reconstructing the Matacavalos home: "o meu fim em imitar a outra foi ligar as duas pontas da vida, o qual aliás não alcancei". ASSIS, cit.

${ }^{51}$ ASSIS, cit.

${ }^{52}$ Idem.

${ }^{53}$ Ibidem.
} 
E antes seja olvido que confusão; explico-me. Nada se emenda bem nos livros confusos, mas tudo se pode meter nos livros omissos. Eu quando leio algum desta outra casta, não me aflijo nunca. O que faço, em chegando ao fim, é cerrar os olhos e evocar todas as coisas que não achei nele. [...] É que tudo se acha fora de um livro falho, leitor amigo. Assim preencho as lacunas alheias; assim podes também preencher as minhas. ${ }^{54}$

This section is perhaps the most important in understanding the relationship between narrator and reader. Dom Casmurro explains that when he finds omissions in books, he fills the gaps with his own thoughts. And he invites his readers to do the same. He alludes to the notion that his narration also contains omissions, due to forgetfulness and confusion, thus opening the possibility for his readers to fill in those gaps.

Building on Barthes's concept of the death of the author, as well as Umberto Eco's notion of the open text, Antonio Luciano Tosta explores the "entreabertura"55 of Machado's narrative. This state of being halfway open, an "in-betweeness", resides in Machado's use of authorial power while allowing the reader to fill in the gaps and breathe life into the text. All metafiction, according to Linda Hutcheon, "demands that [the reader] participate, that he engage himself intellectually, imaginatively, and affectively in its co-creation". ${ }^{56}$ Moreover, Dom Casmurro creates a textual space that not only permits but requires the participation of active readers, as Hélio de Seixas Guimarães observes:

É como se a tessitura do texto se alargasse e as fissuras - contradições, omissões, emendas, lacunas - construíssem um espaço, digamos, interno, capaz de abrigar leituras discordantes entre si, variáveis em função da projeções que o leitor empírico faz dos seus próprios valores e crenças sobre o texto radicalmente ambíguo do romance. ${ }^{57}$

These "leituras discordantes", however, allow readers to bring their own values and beliefs into the process of co-creation, thus creating paradoxical relationships between author, narrator, and reader. Dixon states:

\footnotetext{
${ }^{54}$ Ibidem.

55 TOSTA, Machado de Assis: A obra entreaberta, p. 37.

${ }^{56}$ HUTCHEON, Narcissistic Narrative, p. 7

${ }^{57}$ GUIMARÃES, Dom Casmurro e o leitor lacunar, p. 216.
} 
The fact that the narrator provides contradictory evidence, and even suggests that the reader may want to "preencher as lacunas" (chap. LIX) in his text, creates a narrative conundrum going beyond the question of the speaker's "reliability" or "unreliability". Because he informs the reader that his tale is suspect, he is paradoxical, as in the case of the famous "liar paradox" [...] and creates a situation where one must believe in order to disbelieve, or vice versa. ${ }^{58}$

The paradoxical narrator invites the reader as co-conspirator in the creation process to fill in the gaps of his life, and by so doing, Dom Casmurro further destabilizes the central arguments of his narration. Guimarães argues that by inviting another to finish his story, Dom Casmurro reveals his incomplete nature both as narrator and as "vivenciador das experiências relatadas". ${ }^{59}$ Likewise, the reader becomes "uma espécie de extensão complementar do narrador, também incompleto, cindido". ${ }^{60}$

On a metanarrative level, it can be argued that at this point in the novel Machado de Assis inserts himself into the text and speaks directly to the external reader through the voice of Dom Casmurro. If readers have not grasped it by now, Machado infers that this text - the novel Dom Casmurro is unlike other texts, which rely on a more passive reader. Readers of Machado's new kind of narrative, therefore, must actively engage in ascribing meaning and in drawing conclusions. The recipient of ScottBuccleuch's translation, however, does not have access to these instructions and misses out on the greater theoretical implications of the novel. Conceivably, readers could intuit the overall metanarrative purpose of the novel based on self-reflective comments found elsewhere, but the fact remains that this particular chapter explicitly summarizes Machado de Assis's aim to openly include readers in the process of constructing and interpreting the text. Scott-Buccleuch's decision to omit this section severely weakens and distorts the metanarrative and metafictional relationships.

In the following chapter, "Querido opúsculo", Dom Casmurro continues his train of thought. He rereads chapter 58 about the "cocadas" and comments that after he wrote that section he let out a cry of "saudade". He then asked a musician friend to transcribe this cry into musical notation so that he could add it as an addendum to the chapter. After showing the transcription to another musician, who sees it as uninspiring, Dom

\footnotetext{
${ }^{58}$ DIXON, Machado de Assis, the 'Defunto Autor' and the Death of the Author, p. 50.

${ }^{59}$ GUIMARÃES, cit., p. 222-223.

${ }^{60}$ Idem, p. 223.
} 
Casmurro removes it. He then makes the following comment about selfediting: "Para que não aconteça o mesmo aos outros profissionais que porventura me lerem, melhor é poupar ao editor do livro o trabalho e a despesa da gravura. Vês que não pus nada, nem ponho". ${ }^{61}$ This section exhibits several important points beyond the self-referential intertextuality. First, Dom Casmurro reveals to the reader that he claims to be a selfmonitoring and self-editing writer. Second, the authoritative opinions of his readers carry significant weight. Third, the fact that Dom Casmurro admits to going back and editing his text, which is his prerogative, gives the reader cause to wonder what else the narrator has retrospectively altered, and why. Dom Casmurro has already invited readers to fill in the gaps of his story; this section further enhances their collaborative relationship. Scott-Buccleuch decides this chapter is not needed and removes it from his translation.

The "elliptical but essential middle section of the novel", ${ }^{62}$ exemplified by these three chapters, exhibits the unreliability of the narrator, while also emphasizing the importance of an active, participatory reader. ScottBuccleuch's suppression of these nine chapters, therefore, undermines readers' ability to unweave Dom Casmurro's intricate narrative web, limiting their ability to appreciate the technical and theoretical brilliance of Machado de Assis. As a result, readers come away missing the great achievement of the novel: their participation is not merely desirable but indispensable. Without these chapters, the reader of Scott-Buccleuch's translation has no chance to see Dom Casmurro slowly fray his argumentative thread by obliquely admitting that his own story contains gaps and omissions. Dom Casmurro reveals the blind spot of his own narration, the removal of which becomes the blind spot of the Scott-Buccleuch translation.

Returning to the metaphor of prestidigitation, one of the key components of close-up magic is misdirection, that is, simultaneously distracting the audience's attention from one aspect while focusing it onto another. Scott-Buccleuch, as a close reader of Dom Casmurro, performs a feat of textual sleight of hand. While our attention is focused on the excision of nine chapters, his translation distracts us from the fact that his choices as translator emulate many of the same "narrative sleights-of-hand"63 performed by the novel's titular narrator. Nevertheless, the result of ScottBuccleuch's decisions to remove, reshape, and merge key sections of the

\footnotetext{
${ }^{61}$ ASSIS, cit.

62 PATAI, cit., p. 96.

${ }^{63}$ DIXON, Machado de Assis, the 'Defunto Autor' and the Death of the Author, p. 50.
} 
novel is not a mirroring of Machado's techniques; rather, it is a pale imitation that disrupts and limits readers' ability to engage with the underlying metanarrative structure. Furthermore, as Scott-Buccleuch elides, digresses, and redacts, he more fully embodies Dom Casmurro's unreliability.

In "Reconsidering Unreliability: Fallible and Untrustworthy Narrators", Greta Olson revisits and updates studies on unreliable narration, including those of Wayne Booth, Ansgar Nünning, Monika Fludernik, James Phelan and Mary Patricia Martin, as well as others. With slight modifications, Olson's observations can be applied to our discussion of ScottBuccleuch as a highly engaged, yet misguided, reader. In the same way Dom Casmurro is an unreliable narrator we can also consider Scott-Buccleuch an unreliable translator. Using Olson's approach to unreliable narrators, we can consider Scott-Buccleuch not just "fallible" but "untrustworthy" as a translator. Olson sees shortcomings in Booth's and Nünning's models and proposes that unreliability falls along a spectrum. At one end reside fallible narrators "who do not reliably report on narrative events because they are mistaken about their judgments or perceptions or are biased". ${ }^{64}$ Many of their mistakes in narrating reliably are based on circumstances rather than "inherent characteristics". ${ }^{65}$ Untrustworthy narrators, on the other end, "strike [readers] as being dispositionally unreliable. The inconsistencies these narrators demonstrate appear to be caused by ingrained behavioral traits or some current self-interest". ${ }^{66}$ One could argue that, in part, Dom Casmurro's unreliability fits this description. But what happens when we move beyond the discussion of unreliable narrators and extrapolate Olson's argument to include "fallible" and "untrustworthy" translators? Fallible translators who make the occasional mistake due to situational or circumstantial limitations deserve readers' patience and understanding. Even the most accomplished translators are bound to make take a linguistic or cultural misstep from time to time. Untrustworthy translators, however, consistently misinterpret, misconstrue, and misrepresent the original text. Scott-Buccleuch exhibits a pattern of translational decisions that impede readers' ability to fully interpret and, consequently, appreciate Machado's metanarrative brilliance.

In "Translating Machado de Assis", John Gledson analyzes three translations of Dom Casmurro - Helen Caldwell's, Scott-Buccleuch's, and his own - in a side-by-side comparison. In his meticulous study, he criticizes

\footnotetext{
${ }^{64}$ OLSON, Reconsidering Unreliabilty: Fallible and Untrustworthy Narrators, p. 101.

${ }^{65} \mathrm{Idem}, \mathrm{p} .102$.

${ }^{66}$ Ibidem.
} 
many of the lexical and syntactic liberties Scott-Buccleuch takes, stating: "[he] will quite readily stray from the original [...] in ways that seem trivial; in fact, the slight distortions accumulate and give a wrong picture". ${ }^{67}$ Commenting on one of José Dias's famous superlatives, Gledson observes: "Scott-Buccleuch's solution seems too far from the central meaning of the Portuguese to be satisfactory". ${ }^{68}$ When confronted with tricky words or phrases, he frequently "give[s] up"69 in finding a suitable equivalent and, "in his cavalier way", ${ }^{70}$ either rewrites it or removes it entirely. Gledson points out additional mistakes and misreadings, but saves his full excoriation until the end. Scott-Buccleuch translates the culturally-specific term agregado as "friend of the family", which Gledson considers disastrous. He states: "Such mistranslations of key words contribute to making the whole novel an unsolvable enigma to the reader, and are much more important than minor, subtle nuances of meaning, for their importance is structural" ${ }^{71}$ In one of few studies to examine and evaluate Scott-Buccleuch's translation, Gledson presents compelling evidence of systematic and consistent patterns of errors. His analysis, coupled with our in-depth discussion of the excised chapters, leads us to conclude that Scott-Buccleuch demonstrates inconsistencies that "appear to be caused by ingrained behavioral traits". ${ }^{72}$ Consequently, on the spectrum of translator reliability, Scott-Buccleuch leans towards "untrustworthy".

By introducing elisions and concealing information, the translator unexpectedly evokes the autodiegetic narrator's own approach to selfnarration. Nevertheless, Machado de Assis purposefully weaves a metanarrative throughout the novel, which undermines the narrator's reliability. Scott-Buccleuch, however, includes no such meta-commentary of his translation, thus leading to his own unreliability as translator. Analyzing this particular translation, however, ultimately enriches our understanding of the narrative practices of Machado de Assis.

\footnotetext{
${ }^{67}$ GLEDSON, Translating Machado de Assis/Traduzindo Machado de Assis, p. 34.

${ }^{68} \mathrm{Idem}$, p. 35.

${ }^{69}$ Idem, p. 37.

${ }^{70}$ Idem, p. 38

${ }^{71}$ Idem, p. 40

72 OLSON, cit., p. 102.
} 


\section{References}

ALMEIDA, José Américo de. Trash. Trans. R. L. Scott-Buccleuch. London: Peter Owen, 1978.

ALMEIDA, Tarciana Alves. Três traduções de Dom Casmurro. MA thesis. Centro de Ensino Superior de Juiz de Fora, 2014.

ASSIS, Machado de. Dom Casmurro. Trans. John Gledson. New York: Oxford UP, 1997.

Dom Casmurro. Trans. Helen Caldwell. Berkeley, CA: University of California Press, 1966.

. Dom Casmurro. Trans. R. L. Scott-Buccleuch. London: Penguin, 1994.

Epitaph of a Small Winner. Trans. William Grossman. New York: Noonday,

1952. Trans. of Memórias póstumas de Brás Cubas. Rio de Janeiro: 1881.

. Lord Taciturn. Trans. R. L. Scott-Buccleuch. London: Peter Own, 1992.

Posthumous Memoirs of Bras Cubas. Trans. Gregory Rabassa. New York:

Oxford UP, 1997.

Quincas Borba. Trans. Gregory Rabassa. New York: Oxford UP, 1998.

Romances e contos em hipertexto. Ed. Marta de Senna. Fundação Casa de Rui

Barbosa, CNPq, and Faperj, 2007-2009. Web:

http://machadodeassis.net/hiperTx_romances/index.asp, 30 Sep. 2015.

. The Wager: Aires' Journal. Trans. R. L. Scott-Buccleuch. London: Peter

Owen, 1990.

. Yayá Garcia. R. L. Scott-Buccleuch. London: Peter Owen, 1976.

BAPTISTA, Abel Barros. O legado Caldwell, ou o paradigma do pé atrás. Santa Barbara Portuguese Studies 1, p. 145-177, 1994.

BARBOSA, Heloisa Gonçalves. The Virtual Image: Brazilian Literature in English Translation. Diss. University of Warwick, 1994. Warwick, UK. Web: http://wrap.warwick.ac.uk/56829/, 30 Sep. 2015.

BARRETO, Lima. The Patriot. Trans. R. L. Scott-Buccleuch. London: Collings, 1978.

BLOOM, Harold. Genius: A Mosaic of One Hundred Exemplary Creative Minds. New York: Warner, 2001.

BOOTH, Wayne C. The Rhetoric of Fiction. Chicago: University of Chicago Press, 1961.

CALDWELL, Helen. The Brazilian Othello of Machado de Assis. Perspectives in Criticism. Berkeley, CA: University of California Press, 1960.

CÂMARA, Joaquim Mattoso, Jr. Machado de Assis e as referências ao leitor. Ensaios machadianos. Ed. Carlos Eduardo Falcão Uchôa. Rio de Janeiro: Ao Livro Técnico, 1977.

DINNEEN, Mark. Dom Casmurro. Encyclopedia of Literary Translation into English: $M-Z$, Vol. 2. Ed. Olive Classe. London: Fitzroy Dearborn, 2000, p. 879-881.

DIXON, Paul. A autorreferência e o paradoxo em Dom Casmurro. Brasil/Brazil, vol. 1, n. 1, p. 30-40, 1988. 
Dom Casmurro e o leitor. Nos labirintos de Dom Casmurro. Ed. Juracy Assmann Saraiva. Porto Alegre: EDIPUCRS, 2005, p. 209-23, Coleção Literatura Brasileira: Série Grandes Obras.

Machado de Assis, the 'Defunto Autor', and the Death of the Author. LusoBrazilian Review, vol. 46, n. 1, p. 45-55, 2009.

FITZ, Earl E. John Barth, Machado de Assis, and 'The Literature of Exhaustion': the Reception of Brazilian Literature in the United States During the 'Boom' Years. Comparatist 10, p. 56-67, 1986.

Machado de Assis. Twayne's World Author Series. Ed. David Foster. Boston: Twayne, 1989.

The Reception of Machado de Assis in the United States During the 1950s and 1960s. Luso-Brazilian Review, vol. 46, n. 1, p. 16-35, 2009.

GHOSE, Zulfikar. Reading Joaquim Maria Machado de Assis. Context 12, 2003. Web: http://www.dalkeyarchive.com/reading-joaquim-maria-machado-deassis/, 30 Sep. 2015.

GLEDSON, John. Translating Machado de Assis/Traduzindo Machado de Assis. Trad. Luana Ferreira de Freitas. Scientia Traductionis 14, p. 6-63, 2013.

GONZÁLEZ ECHEVARRÍA, Roberto, ed. Introduction. The Oxford Book of Latin American Short Stories. New York: Oxford UP, 1997.

GUIMARÃES, Hélio de Seixas. Os leitores de Machado de Assis: o romance machadiano e o público de literatura no século 19. São Paulo: Nankin/Edusp, 2004.

HANSEN, João Adolfo. Dom Casmurro, The Fruit and the Rind: An Afterword. Dom Casmurro. Trans. John Gledson. New York: Oxford UP, 1997, p. 245-57.

HUTCHEON, Linda. Narcissistic Narrative: The Metafictional Paradox. New York: Methuen, 1985.

JACKSON, K. David. Machado de Assis in English: A Selected Bibliography. The Author as Plagiarist - The Case of Machado de Assis. Dartmouth, MA: Center for Portuguese Studies and Culture, 2006, p. 627-646, Portuguese Literary and Cultural Studies 13/14.

Madness in a Tropical Manner. Rev. of The Posthumous Memoirs of Brás Cubas, by Machado de Assis, trans. Gregory Rabassa and Dom Casmurro, by Machado de Assis, trans. John Gledson. New York Times, 22 Feb. 1998.

KREMER, Lucia Maria Silva. Desvendando saberes: O caso da tradução de Dom Casmurro para o inglês. Saberes Docentes: VII Congresso Nacional de Educação EDUCERE; $V$ Encontro Nacional de Atendimento ao Escolar Hospitalar. Pontifícia Universidade Católica do Paraná. 5-8 nov. 2007. Web: http://www.pucpr.br/eventos/educere/educere2007/anaisEvento/arquivos/CI -487-03.pdf, 30 Sep. 2015.

MAC ADAM, Alfred. Dead Man Talking. Rev. of The Posthumous Memoirs of Bras Cubas [trans. Gregory Rabassa] and Dom Casmurro [trans. John Gledson]. Los Angeles Times, 5 May 1996. 
MOREIRA, Paulo. O lugar de Machado de Assis na república mundial das letras. Machado de Assis em linha. v. 2, n. 4, p. 96-107, 2009. Web: http://machadodeassis.net/revista/numero04/rev_num04_artigo05.asp, $30 \mathrm{Sep}$. 2015.

NIELSON, Rex P. A repetição e os retratos do pai e do filho em Dom Casmurro. Espelho: Revista Machadiana 12/13, p. 29-43, 2006-7.

NÜNNING, Ansgar. Unreliable Narration zur Einführung: Grundzüge einer kognitiv-narratologischen Theorie und Analyse unglaubwürdigen Erzählens. Unreliable Narration: Studien zur Theorie und Praxis unglaubwürdigen Erzählens in der englischsprachigen Erzählliteratur. Ed. Ansgar Nünning. Trier: WVT, 1998, p. 3-40.

OLSON, Greta. Reconsidering Unreliability: Fallible and Untrustworthy Narrators. Narrative, vol. 11, n. 1, p. 93-109, 2003.

PATAI, Daphne. Machado in English. Machado de Assis: Reflections on a Brazilian Master Writer. Ed. Richard Graham. Austin: University of Texas Press, 1999, p. 85-116.

PEIXOTO, Marta. Dom Casmurro by Machado de Assis. Ed. Efraín Kristal. Cambridge: Cambridge UP, 2005, p. 219-231, The Cambridge Companion to the Latin American Novel.

RABASSA, Gregory. No Two Snowflakes are Alike: Translation as Metaphor. The Craft of Translation. Eds. John Biguenet and Rainer Schulte. Chicago: University of Chicago Press, 1989, p. 1-12.

RABINOWITZ, Peter J. Truth in Fiction: A Reexamination of Audiences. Critical Inquiry 1, p. 121-141, 1977.

RAMOS, Graciliano. São Bernardo. Trans. R. L. Scott-Buccleuch. New York: Taplinger, 1979.

ROHTER, Larry. After a Century, a Literary Reputation Finally Blooms. New York Times 12 Sep. 2008, B9.

SANT'ANNA, Affonso Romano de. Atentado contra Machado. O Globo, 5 ago. 1997.

SANTIAGO, Silviano. Retórica da verossimilhança. Uma literatura nos trópicos: ensaios sobre dependência cultural. São Paulo: Perspectiva, 1978, o. 29-48.

SCHWARZ, Roberto. Um mestre na periferia do capitalismo. São Paulo: Livraria Duas Cidades, 1990.

SCOTT-BUCCLEUCH, Robert L., trans. Introduction. Dom Casmurro. London: Penguin, 1994.

SONTAG, Susan. Afterlives: The Case of Machado de Assis. In: Where the Stress Falls: Essays. New York: Farrar, Straus and Giroux, 2001, p. 30-40. Originally published in The New Yorker, 7 May 1990, p. 102.

TOSTA, Antonio Luciano. Machado de Assis: A obra entreaberta. Luso-Brazilian Review, vol. 41, n. 1, p. 37-55, 2004.

TURNER, Doris J. A Clarification of Some 'Strange' Chapters in Machado's Dom Casmurro. Luso-Brazilian Review, vol. 13, n. 1, p. 55-66, 1976. 
TRADUÇÃO inglesa altera livro de Machado de Assis. O Globo, 6 Aug. 1997.

UPDIKE, John. Conversations with John Updike. Jackson: UP of Mississippi, 1994.

VALLE, Ivonne del. Os narradores de Machado de Assis. Espelho: Revista Machadiana, 6/7, p. 97-131, 2000-1.

WOOD, Michael. Master among the Ruins. New York Review of Books, 9 Jul. 2002, 49.12 .

JAMES R. KRAUSE is an assistant professor of Portuguese and Spanish at Brigham Young University (Provo, UT, EUA). His teaching and research interests include comparative Latin American literature, fantastic short fiction of the Southern Cone, and the reception of João Guimarães Rosa in English. Recent publications have appeared in Chasqui, Decimonónica, and Clássicos em Tradução, Rotas e Percursos. E-mail: jameskrause@byu.edu. 